\title{
Proximal causes of genetic variation between and within populations of raulí (Nothofagus nervosa)
}

\author{
Basilio Carrasco ${ }^{1}$, Maurice Garnier ${ }^{1}$, Lafayette Eaton ${ }^{2}$, Rafael Guevara ${ }^{2}$, and \\ Margarita Carú ${ }^{2}$ \\ ${ }^{1}$ Departamento de Fruticultura y Enología, Facultad de Agronomía e Ingeniería Forestal, Pontificia \\ Universidad Católica de Chile. Casilla 306-22. Santiago. Chile. \\ ${ }^{2}$ Departamento de Ciencias Ecológicas, Facultad de Ciencias, Universidad de Chile. Casilla 653. Santiago. Chile.
}

\begin{abstract}
B. Carrasco. M. Garnier. L. Eaton. R. Guevara, and M. Carú. 2009. Proximal causes of genetic variation between and within populations of raulí (Nothofagus nervosa). Cien. Inv. Agr. 36(2):229-238. Random Amplified Polymorphic DNA(RAPD) markers were used to assess the genetic diversity of 587 individuals, belonging to 22 populations of Nothofagus nervosa that were distributed through the Coastal $\left(38^{\circ} \mathrm{S}\right.$ to $\left.41^{\circ} \mathrm{S}\right)$ and Andes Mountains in CentralSouthern Chile $\left(36^{\circ} \mathrm{S}\right.$ to $\left.40^{\circ} \mathrm{S}\right)$. The objective of this study was to complement the genetic inferences previously determined by isozyme analysis, in order to obtain more accurate genetic diversity estimations. We scored $81.8 \%$ of the polymorphic loci of the samples tested. The average incidence of genetic polymorphism within populations was high, with values ranging between 33\% and 63\%. Analysis of molecular variance (AMOVA) showed most of the genetic variation was distributed within populations $(87.6 \%)$, but $\mathrm{F}_{\mathrm{ST}}$ values $\left(\mathrm{F}_{\mathrm{ST}}=0.124 ; \mathrm{p}<0.00001\right)$ indicated that there was also a significant difference among populations. A discriminant analysis revealed three geographically defined groups and showed that 14 loci explained $87.2 \%$ of the genetic differentiation among $N$. nervosa populations. Watterson's neutrality test and Ohta's two-locus analysis of linkage disequilibrium (LD) both suggested that stochastic demographic and environmental factors can partially explain the loci variation observed in the RAPDs. The role of the last glaciations, as well as some conservation and breeding strategies, may have influenced current genetic variation and fragmentation in this species.
\end{abstract}

Key words: Genetic structure, Nothofagus, RAPD markers.

\section{Introduction}

Nothofagus is an important genus of the temperate forests of South America. Traditionally, the genus Nothofagus was classified as a member of the Fagaceae family. However, this genus has recently been included in the monogeneric

Received 15 September 2008. Accepted 27

December 2008.

Corresponding author: bcarrasco@uc.cl. family Nothofagaceae, based on morphological, developmental, and biogeographical studies (Veblen et al., 1996; Souza et al., 2000). In Chile, there are nine species of Nothofagus, including N. nervosa (Phil.) Dim. et Mil. ("raulí"), which is a large deciduous tree that grows in the Chilean Andes from $36^{\circ} \mathrm{S}$ to just south of $40^{\circ} \mathrm{S}$. Nothofagus nervosa is also found in the Coastal Mountains, from $38^{\circ} \mathrm{S}$ to $41^{\circ} \mathrm{S}$, and has been identified in a few stands in Argentina near the Chilean border (Donoso. 1995). Nothofagus nervosa grows on the lower slopes of the Andes, 
at altitudes from 100 to $1200 \mathrm{~m}$, forming mixed forests with $N$. dombeyi (Mirb.) Oerst. ("coigüe") and sometimes N. obliqua (Mirb.) Oerst. ("roble"). However, "raulí" generally grows at higher altitudes than "roble".

Nothofagus nervosa is a monoecious species that is largely outcrossing, with predominantly wind-dispersed pollen and seeds (Donoso, 1995). Most of the "raulí" populations from the Coastal Mountain Range have become extinct, while the remaining populations have been reduced to dispersed and small patches, due to intensive use of the plant as a wood source. Genetic differentiation may be expected, considering the geographic separation and isolation of some natural populations of $N$. nervosa in both the Andes and coastal mountains. It is known that habitat fragmentation can result in a loss of genetic variability and, in the long term, can cause genetic differentiation between populations, resulting in a loss of fitness (Garcia et al., 2008). It would be surprising if the natural populations of "raulí" have escaped this process during their natural history.

Previous reports (Carrasco, 1998; Carrasco and Eaton, 2002) based on 10 isozyme loci have revealed a moderate level of variability between populations of "raulí". However, the data obtained from these studies cannot support any realistic inference about the evolutionary process and conservation plans for this species, because of the low level of genetic resolution given by isozyme loci.

In order to complement the genetic inferences previously determined by isozyme analysis (Carrasco and Eaton, 2002), the genetic diversity between and within populations of raulí was studied using an alternative molecular marker, such as randomly amplified polymorphic DNA (RAPD) (Welsh and McCLelland, 1990; Williams et al.,1990; Hadrys et al., 1992), and a larger sample size of 586 individuals from 22 distinct populations of $N$. nervosa from central and southern Chile (Figure 1). The populations studied were found in both the Andean and Coastal mountains, representing the complete natural distribution of the species in Chile. Therefore, the data obtained from this study will permit us to examine the possible causes of the observed pattern of genetic variation, and to compare our results with other studies that have used dominant molecular markers in forest species.

\section{Materials and methods}

\section{Populations studied}

The geographic locations of the 22 populations of $N$. nervosa sampled are indicated in Table 1 and Figure 1. A total of 586 individuals were analyzed in this study. Each individual was sampled randomly, with at least $30 \mathrm{~m}$ between trees, to minimize sampling among relatives. Terminal and lateral branch samples were collected, including at least six new leaves from each individual. Leaves were frozen in liquid nitrogen until they were processed for DNA extraction.

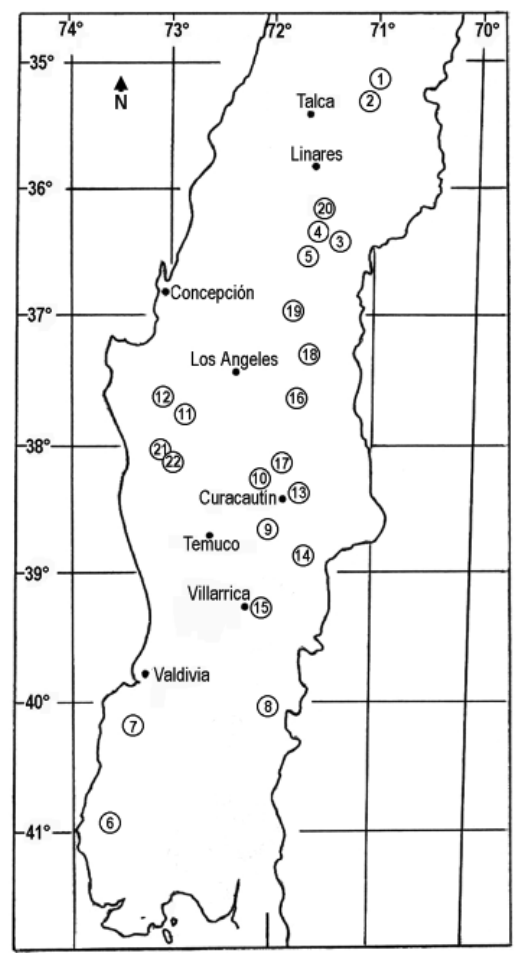

Figure 1. Map of central Chile, showing the actual range of Nothofagus nervosa. Numbers indicate the studied populations: 1 Aguas Frias, 2 Vilches, 3 San Fabian Alto, 4 San Fabian Bajo, 5 Recinto, 6 El Colegual, 7 Las Trancas, 8 Maihue, 9 Cherquenco, 10 Selva Oscura, 11 Angol, 12 Nahuelbuta, 13 Curacautin, 14 Melipeuco, 15 Villarica, 16 Ralco, 17 Laguna, Malleco, 18 Antuco, 19 Monte León, 20 Bullileo, 21, Villa Araucária, 22 Capitán Pastenes. 
Table 1. Geographic data of populations of Nothofagus nervosa ("raulí") sampled to determine genetic variation by Random Amplified Polymorphic DNA.

\begin{tabular}{|c|c|c|c|c|}
\hline Populations & $\begin{array}{c}\text { Mountain } \\
\text { Ranges }\end{array}$ & $\begin{array}{c}\text { Latitude } \\
\text { South }\end{array}$ & $\begin{array}{c}\text { Longitude } \\
\text { West }\end{array}$ & $\begin{array}{c}\text { Altitude } \\
\mathrm{m}\end{array}$ \\
\hline 1. Aguas Frías & Andes & $35^{\circ} 21^{\prime}$ & $71^{\circ} 04^{\prime}$ & 650 \\
\hline 2. Vilches & Andes & $35^{\circ} 27^{\prime}$ & $71^{\circ} 08$ & 850 \\
\hline 3. San Fabian Alto & Andes & $36^{\circ} 39^{\prime}$ & $71^{\circ} 33^{\prime}$ & 750 \\
\hline 4. San Fabian Bajo & Andes & $36^{\circ} 34^{\prime}$ & $71^{\circ} 38^{\prime}$ & 450 \\
\hline 5. Recinto & Andes & $36^{\circ} 49^{\prime}$ & $71^{\circ} 41^{\prime}$ & 750 \\
\hline 6. El Colegual & coastal & $40^{\circ} 56^{\prime}$ & $73^{\circ} 28^{\prime}$ & 238 \\
\hline 7. Las Trancas & coastal & $40^{\circ} 15^{\prime}$ & $73^{\circ} 20^{\prime}$ & 150 \\
\hline 8. Maihue & Andes & $40^{\circ} 13^{\prime}$ & $71^{\circ} 59^{\prime}$ & 250 \\
\hline 9. Cherquenco & Andes & $38^{\circ} 40^{\prime}$ & $71^{\circ} 57^{\prime}$ & 300 \\
\hline 10. Selva Oscura & Andes & $38^{\circ} 19^{\prime}$ & $72^{\circ} 05^{\prime}$ & 350 \\
\hline 11. Angol & coastal & $37^{\circ} 47^{\prime}$ & $72^{\circ} 50^{\prime}$ & 530 \\
\hline 12. Nahuelbuta & coastal & $37^{\circ} 40^{\prime}$ & $73^{\circ} 13^{\prime}$ & 950 \\
\hline 13. Curacautín & Andes & $38^{\circ} 27^{\prime}$ & $71^{\circ} 44^{\prime}$ & 750 \\
\hline 14. Melipeuco & Andes & $38^{\circ} 51^{\prime}$ & $71^{\circ} 38^{\prime}$ & 750 \\
\hline 15. Villarrica & Andes & $39^{\circ} 27^{\prime}$ & $72^{\circ} 13^{\prime}$ & 310 \\
\hline 16. Ralco & Andes & $37^{\circ} 40^{\prime}$ & $71^{\circ} 40^{\prime}$ & 150 \\
\hline 17. Laguna Malleco & Andes & $38^{\circ} 14^{\prime}$ & $71^{\circ} 50$ & 850 \\
\hline 18. Antuco & Andes & $37^{\circ} 23^{\prime}$ & $71^{\circ} 32^{\prime}$ & 710 \\
\hline 19. Monte León & Andes & $37^{\circ} 01$ & $71^{\circ} 49^{\prime}$ & 650 \\
\hline 20. Bullileo & Andes & $36^{\circ} 26^{\prime}$ & $71^{\circ} 37^{\prime}$ & 720 \\
\hline 21. Villa Araucanía & coastal & $38^{\circ} 05^{\prime}$ & $73^{\circ} 10^{\prime}$ & 250 \\
\hline 22. Capitán Pastene & coastal & $38^{\circ} 10^{\prime}$ & $72^{\circ} 58^{\prime}$ & 280 \\
\hline
\end{tabular}

\section{DNA isolation and PCR amplification}

High quality DNA was obtained using a CTAB (hexadecyltrimethylammonium bromide) based protocol, adapted from Doyle (1991). PCR amplification was performed in a GeneAmp 2400 (Perkin Elmer Co., Norwalk, CT, USA) thermal cycler, with the following program: 5 min predenaturation at $94^{\circ} \mathrm{C}$ followed by 40 cycles of $1 \mathrm{~min}$ denaturation at $92^{\circ} \mathrm{C}, 1 \mathrm{~min}$ annealing at $36^{\circ} \mathrm{C}$, and $1 \mathrm{~min}$ extension at $72^{\circ} \mathrm{C}$, with a final extension of $5 \mathrm{~min}$ at $72^{\circ} \mathrm{C}$. The amplification reaction contained $10 \mathrm{mM}$ Tris, $50 \mathrm{mM} \mathrm{KCl}$,
$2 \mathrm{mM} \mathrm{MgCl}, 0.1 \mathrm{mM}$ of each dNTP, $0.4 \mathrm{mM}$ primer, 2.5 units of Taq polymerase (GIBCOBRL) and 20 ng template DNA. A negative control without DNA template was added to each run to test for contamination. Ten arbitrary primers were screened (kit OPBF, Operon Technologies, Alameda. CA, USA), but only two primers (OPBF-02, 5'GAC ACA CTC C3' and OPBF-18, 5'AGC CAA GGA C3') produced repeatable and consistent band patterns and were therefore used for further analyses.

The amplification products were separated by electrophoresis on $1.4 \%$ agarose gels and visu- 
alized under UV light after staining in ethidium bromide. PCR reactions and electrophoreses were repeated at least twice to assure the reproducibility of the bands.

\section{Data scoring and analysis}

The size of the PCR products was determined using the Kodak Digital Science ID program (Eastman Kodak Co., Rochester, NY, USA). Only reproducible bands were scored as present (1) or absent (0). Two assumptions were made in RAPD statistical analyses: (1) co-migrating bands were homologous; and (2) different band positions represented different loci. To estimate polymorphism parameters in the populations, the presence/absence data matrix was analyzed with POPGENE 1.31 (Yeh et al., 1999). This program calculates the polymorphic loci percentage $(\mathrm{P})$. Shannon's index $(\mathrm{S})$ is known as phenotypic diversity $[\mathrm{S}=-p i(\log 2 p i)]$, where $p i$ is the proportion of individuals having a band at a particular locus, averaged by the number of polymorphic loci in each population. A large score indicates large genetic diversity in the population. Shannon's index and $95 \%$ confidence intervals of Shannon's index were estimated using 1000 bootstrap samples. Nei's gene diversity (H) was also estimated (Nei, 1973, 1978).

The distribution of genetic diversity within and among populations $\left(\mathrm{F}_{\mathrm{st}}\right)$ was calculated using the analysis of molecular variance (AMOVA, Excoffier et al., 1992). A discriminant analysis (DA) was performed in order to determine relationships among populations and to determine which loci explain those differences. For this analysis, Statistica 4.5 software (StatSoft Inc., Tulsa, OK USA) was used, and only polymorphic loci were included. The DA was applied because is a more sensitive method of revealing relationships among populations, as it does not impose a hierarchical structure, such as a dendrogram, and it allows misclassified individuals and populations to be identified.
The relationship between genetic distance and geographic distance was analyzed by a Mantel test (Mantel, 1967), using the Mantel Nonparametric Test Calculator package, version 2.00 (Liedloff, 1999).

To detect the possible effects of selection/genetic drift on inter-population allele distribution, the Evens-Watterson test for neutrality (1000 permutations per test) was applied using POPGENE version 1.31 (Yeh, et al., 1999). Linkage disequilibrium (LD) was estimated using Ohta's two-locus analysis for subdivided populations (Ohta, 1982), included in the GENEPOP package version 1.2 (Raymond and Rousset, 1995). A total of 528 loci comparisons $\left(\left[\mathrm{N}(\mathrm{N}-1)^{-2}\right]\right)$ were performed, where $\mathrm{N}=33$ was the number of loci analyzed.

Ohta's approach makes two partitions of the total variance of dilocus $\mathrm{LD}\left(\mathrm{D}_{\mathrm{IT}}^{2}\right)$, within-population and between-population components: $\mathrm{D}_{\text {IS }}^{2}$ (average LD within subpopulations) and $\mathrm{D}^{2}{ }_{\mathrm{ST}}$ (variance of expected "chromosome" frequencies among subpopulations), and $\mathrm{D}^{22}$ (variance of the observed "chromosome" frequencies in subpopulations from the observed totals) and $\mathrm{D}^{\prime 2}{ }_{\mathrm{ST}}$ (variance of the observed totals from the average expected frequencies of the total population) (Ohta, 1982). Ohta's model predicts that $\mathrm{LD}$ is due to random drift if $\mathrm{D}_{\mathrm{ST}}^{2}>\mathrm{D}_{\text {IS }}^{2}$ and $\mathrm{D}^{\prime 2}{ }_{\mathrm{IS}}>\mathrm{D}^{\prime 2}{ }_{\mathrm{ST}}$, and that LD is due to epistatic selection if $\mathrm{D}_{\mathrm{ST}}^{2}<\mathrm{D}_{\text {IS }}^{2}$ and $\mathrm{D}^{\prime 2}{ }_{\mathrm{IS}}<\mathrm{D}^{\prime 2}{ }_{\mathrm{ST}}$. The variances were calculated by adding the squared deviations and calculating weighted averages (Ohta, 1982).

\section{Results}

A total of 33 putative RAPD loci were identified from the 586 individuals analyzed from 22 natural populations. The number of scored bands and size fragments amplified with the different primers ranged from 15 bands to 18 bands, with sizes ranging from 375 to $1900 \mathrm{bp}$ and 650 to $1700 \mathrm{bp}$, respectively. 
As a dominant marker type, RAPDs are visualized by the presence or absence of a band. Therefore, it was assumed that absence of a band indicated that the individual was homozygous for the recessive allele. Calculation of genetic diversity values also assumes that the population is in Hardy-Weinberg equilibrium. At the species level, out of the 33 loci, 27 $(81.8 \%)$ were polymorphic and 6 loci were consistently monomorphic. Shannon's Index (S) and gene diversity were $\mathrm{S}=0.23$ and $\mathrm{H}=0.15$, respectively. At the population level, all statistical tests had decreased average values. The average percentage of polymorphic loci per population and Shannon's Index ranged from $\mathrm{P}=33.3 \%$ to $63.6 \%$ and $\mathrm{S}=0.161$ to 0.284 , respectively (Table 2). Nahuelbuta showed the lowest values $(\mathrm{P}=33.3 \%$. $\mathrm{S}=0.161)$, while Recinto displayed the highest $(\mathrm{P}=63.5 \mathrm{~S}=$ $0.284)$.

Table 2. Shannon's index and polymorphic loci for 33 RAPD loci in 22 populations of Nothofagus nervosa ("raulí") from southern Chile.

\begin{tabular}{|c|c|c|c|}
\hline Populations & Group & Shannon's index & Polymorphic loci (\%) \\
\hline 1. Aguas Frias & A & 0.24 & 45.5 \\
\hline 2. Vilches & A & 0.24 & 45.5 \\
\hline 3. San Fabian Alto & A & 0.26 & 57.6 \\
\hline 4. San Fabian Bajo & A & 0.24 & 54.6 \\
\hline 5. Recinto & A & 0.28 & 63.5 \\
\hline 11. Angol & A & 0.21 & 42.4 \\
\hline 14. Melipeuco & A & 0.21 & 45.5 \\
\hline 16. Ralco & A & 0.25 & 51.5 \\
\hline 18. Antuco & A & 0.20 & 48.5 \\
\hline 19. Monte León & A & 0.22 & 54.6 \\
\hline 20. Bullileo & A & 0.18 & 45.5 \\
\hline Average & & 0.24 & 51 \\
\hline 6. El Colegual & $\mathrm{B}$ & 0.23 & 51.5 \\
\hline 8. Maihue & B & 0.26 & 54.6 \\
\hline 9. Cherquenco & B & 0.25 & 48.5 \\
\hline 10. Selva Oscura & B & 0.24 & 57.6 \\
\hline 12. Nahuelbuta & B & 0.16 & 33.3 \\
\hline 13. Curacautin & B & 0.24 & 54.6 \\
\hline 15. Villarica & B & 0.21 & 45.5 \\
\hline 17. Laguna Malleco & B & 0.24 & 42.4 \\
\hline 21. Villa Araucaria & B & 0.21 & 42.4 \\
\hline 22. Capitán Pastene & B & 0.22 & 54.6 \\
\hline Average & & 0.23 & 48 \\
\hline 7. Las Trancas & $\mathrm{C}$ & 0.22 & 52 \\
\hline
\end{tabular}




\section{Genetic diversity between populations}

The mean value of Nei's genetic distance was $\mathrm{D}=0.047$. In agreement with these results, AMOVA showed that most of the genetic variation was found within populations $(87.6 \%)$, and moderate variation occurs between populations $\left(\mathrm{F}_{\mathrm{ST}}=0.124, \mathrm{p}<0.00001\right)$ (Table 3).
$87.5 \%$ of the variability $(\mathrm{p}<0.05)$. The DA was able to distinguish three population clusters (Figure 2), which were identified as A, B and C. Cluster A included the populations located in the northern area of the natural distribution, through the Andean Mountains: Aguas Frías (1), Vilches (2), San Fabían Alto (3), San Fabian Bajo (4), Recinto (5), Angol (11), Melipeuco (14), Ralco

Table 3. Analysis of molecular variance (AMOVA), using pairwise difference for 22 populations of Nothofagus nervosa ("rauli") and 33 RAPD loci.

\begin{tabular}{lrcccc}
\hline Source of variation & d.f. & $\begin{array}{c}\text { Sum of } \\
\text { squares }\end{array}$ & $\begin{array}{c}\text { Variance } \\
\text { components }\end{array}$ & $\begin{array}{c}\text { Variation } \\
\%\end{array}$ & $\mathrm{p}$ \\
\hline Among populations & 21 & 102.578 & 0.14519 & 12.4 & $<0.000001$ \\
Within populations & 565 & 578.764 & 1.02436 & 87.6 & $<0.000001$ \\
\hline
\end{tabular}

Fixation Index $\mathrm{F}_{\mathrm{ST}}=0.124$. Significance tests over 1000 permutations.

The DA showed that 14 RAPD loci were sufficient for consistent clustering and $100 \%$ of reduction in the classification error (Figure 2). Moreover, a single discriminant function explained
(16), Antuco (18), Monte León (19), and Bullileo (20). The Angol (11) population was the only one located in the Coastal Mountains, and Melipeuco (14) was the southernmost population.

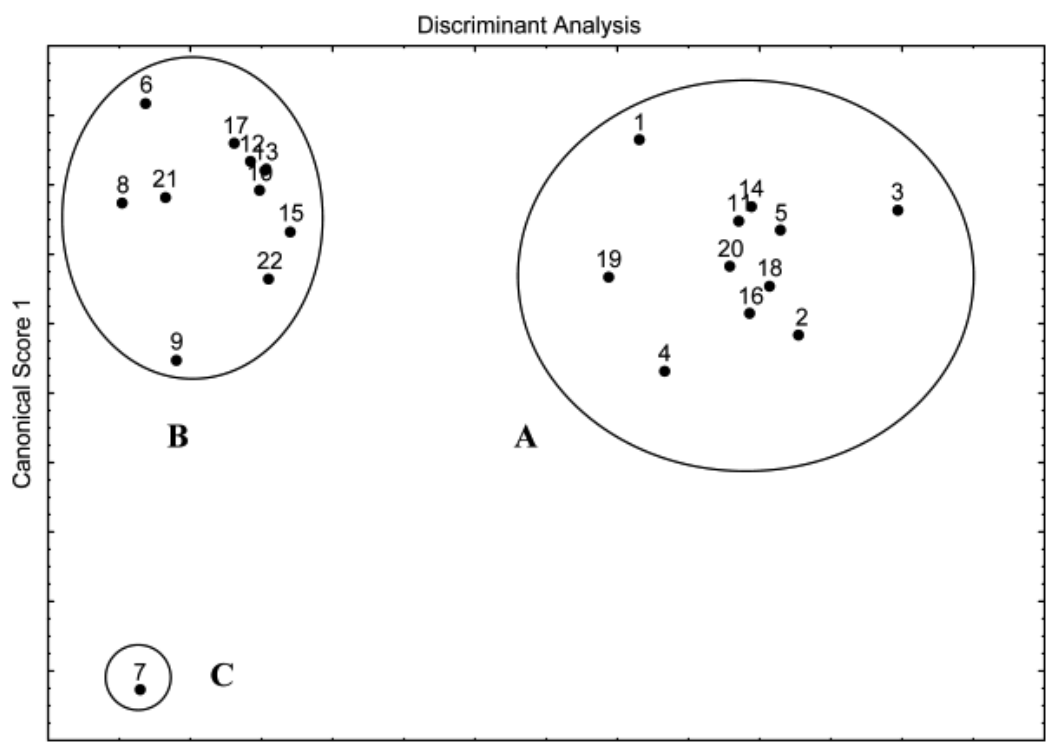

Canonical Score 2

Figure 2. Discriminant analysis of 33 RAPD loci and 22 natural populations of Nothofagus nervosa ("raulí"). $\mathrm{VC} 1=$ canonical variable 1 and CV2 = canonical variable 2 . The 22 populations were separated into 3 clusters: Cluster A included the populations located in the northern area through the Andean Mountains, Cluster B included the populations located in the southern area through the Andean Mountains, and Cluster C included only one population, Las Trancas (7), from the costal Mountains. 
Cluster B included the southern populations located in the Andean Mountains: Maihue (8), Cherquenco (9), Selva Oscura (10), Curacautín (13), Villarrica (15) and Laguna Malleco (17). Cluster $\mathrm{C}$ also included populations from the Coastal Mountains: El Colegual (6), Nahuelbuta (12), Villa Araucanía (21), and Capitán Pastenes (22).

Las Trancas (7), a sample from the Coastal Mountains, was the only population assigned to cluster $\mathrm{C}$.

In agreement with DA, the Mantel test for genetic and geographic distance indicated that raulí populations showed a consistent geographic pattern for genetic variability $(\mathrm{r}=0.469 . \mathrm{p}<0.01)$.

\section{Linkage disequilibrium}

The Evens-Watterson test was not significant for the any of the 33 putative RAPD loci analyzed in this study, indicating that they may be considered as selectively neutral (data not shown). Ohta's test for all 528 loci combinations gave the following average values for the components of total variance of dilocus LD: $\mathrm{D}_{\mathrm{IS}}^{2}=0.0054 ; \mathrm{D}_{\mathrm{ST}}^{2}=0.0738$; $\mathrm{D}^{\prime 2}{ }_{\text {IS }}=0.294 ; \mathrm{D}^{\prime 2}{ }_{\mathrm{ST}}=0.0014 ; \mathrm{D}_{\mathrm{IT}}^{2}=0.2954$. These values are consistent with the expected pattern under Ohta's model in which the relationships among loci are produced by limited migration and genetic drift, but not by epistatic natural selection $\left(\mathrm{D}_{\mathrm{IS}}^{2}<\mathrm{D}_{\mathrm{ST}}^{2}\right.$ and $\mathrm{D}^{{ }_{2}}{ }_{\mathrm{IS}}>\mathrm{D}_{\mathrm{ST}}^{2}$ ). It should be noted that there is essentially no dilocus disequilibrium within populations $\left(\mathrm{D}_{\mathrm{IS}}^{2}=0.0054\right)$, and that almost all the variation in $\mathrm{D}_{\mathrm{IT}}$ is due to differences in allele frequencies among populations $\left(\mathrm{D}^{\prime 2}{ }_{\mathrm{IS}}=0.294\right)$, not to systematic differences in “chromosome" frequencies $\left(\mathrm{D}_{\mathrm{ST}}^{2}=0.0014\right)$.

\section{Discussion}

There has been increasing interest in the use of DNA-based molecular markers for a number of applications in population genetics, conservation and tree improvement. RAPD markers have been used in a wide variety of genetic studies of trees, including Picea abies (L.) Karst. (Bucci and Menozzi, 1995), P. sitchensis (Bong.) Carr. (Van Den Ven and McNicol, 1995), Quercus petraea (Matt.) Liebl. (Le Corre et al., 1997), Andropogon gerardii Vitman (Gustafson et al., 1999) and Pinus leucodermis Antoine (Bucci et al., 1997).

The genetic diversity of "raulí" natural populations $(\mathrm{H}=0.15)$ was low, compared to other plant species. Nybom et al. (2004) showed higher genetic diversity values with dominant molecular markers in other plant species $\left(\mathrm{H}_{\mathrm{RAPD}}=0.22\right.$, $\mathrm{H}_{\mathrm{AFLP}}=0.23, \mathrm{H}_{\mathrm{ISSR}}=0.22$ ). Similarly, RAPD diversity was lower, compared to other long-lived forest species. For example, the mean value of Shannon's index $(\mathrm{S}=0.23)$ was considerably lower than those reported for Araucaria araucana (Molina) K. Koch ( $\mathrm{S}=0.65$, Bekessy et al., 2002), Fitzroya cupressoides (Molina) Johnston ( $\mathrm{S}=0.54$, Allnutt et al., 1999) and Populus tremuloides Michx ( $\mathrm{S}=0.65$, Yeh et al., 1995). The lower RAPD genetic diversity observed in "raulí" populations may be a reflection of the intense exploitation that these populations have suffered during the last century. Almost all natural populations of "rauli" have been replaced by exotic forest trees such as Pinus radiata D. Don and Eucaliptus sp.

Mattioni et al. (2002) found that $87 \%$ of RAPD loci were polymorphic, with a low identity $(\mathrm{I}=0.751)$ among 61 individuals of "raulí". Our results were similar for the polymorphism data $(81.8 \%)$, but very different for identity $(\mathrm{I}=0.96)$. This discrepancy can be explained by our much larger sample size $(\mathrm{N}=586$ individuals). Interestingly, the "raulí" populations revealed less genetic diversity for RAPD markers $(\mathrm{H}=0.15)$ than for allozyme analysis $(\mathrm{H}=0.28$; Carrasco and Eaton, 2002). There are several possible explanations for the difference between variability patterns identified through isozymes and RAPDs. There are intrinsic differences between these two types of genetic markers; RAPD loci have a maximum of two alleles, while isozymes frequently have more than two. Further, heterozygote genotypes can be identified with co-dominant isozymes, while they may only be estimated with dominant RAPDs. Second, the selection regime of RAPDs may be different from that of allozymes (Begun and 
Aquadro, 1993; Baruffi et al., 1995). Previous studies have highlighted the non-neutrality of allozymes (Karl and Avise, 1992), specifically that allozymes are expected to be more susceptible to natural selection than RAPDs. Third, some previous studies have revealed that genetic diversity is greater at RAPD loci than at allozyme loci, suggesting that mutation rates are higher at the RAPD loci (Peakall et al., 1995). Finally, the coverage of the genome is expected to be different between allozymes and RAPDs. In the present study, we examined 33 random putative loci, while only 10 loci were examined in the allozyme study reported by Carrasco and Eaton (2002).

A significant genetic structure was detected for the genetic diversity of RAPDs. AMOVA showed a moderate differentiation between populations $\left(\mathrm{F}_{\mathrm{ST}}=0.12\right)$; this value was lower than the average found in plants for dominant molecular markers (RAPDs $\mathrm{F}_{\mathrm{ST}}=0.34$; $\mathrm{AFLP} \mathrm{F}_{\mathrm{ST}}=0.35$ ISSR F $_{\mathrm{ST}}=0.35$; Nybom, 2004). However, the genetic differentiation among "raulí" populations was similar than other outbreed and wind pollinated Chilean forest species, such as $A$. araucana (RAPDs $\mathrm{F}_{\mathrm{ST}}=0.128$; Bekessy et al., 2002) and Pilgerodendron uviferum (D. Don) Florin (RAPDs $\mathrm{F}_{\mathrm{ST}}=0.186$; Allnutt et al., 2003), but smaller than that of Gomortega keule (ISSR Fst $=0.27$; García et al., 2008).

Moreover, there was an overall correlation between geographic and genetic distance, and the discriminant analysis showed that the populations grouped into three separate geographic zones (Figure 2). Cluster A included forests in the northern part of the species' range in the Andes and the northern part of the Nahuelbuta (coastal) Mountains. Cluster B included populations from more southern parts of both mountain ranges, while cluster $\mathrm{C}$ was composed of the population from Las Trancas, near the southern limit of the species' current range. Clusters A and B included populations from the Nahuelbuta Mountains (populations 11, 12, 21 and 22), which coincides with palynological evidence suggesting that this mountain range was a refuge for this species during the last glaciation (Villagran 1991, 2001). Cluster $\mathrm{C}$ probably represents a second refuge during the last glaciation, in agreement with allozyme variability (Carrasco and Eaton, 2002). Surprisingly, the southernmost population, El Colegual (6), grouped with the populations from the southern Andes (cluster B), and did not appear as an isolated entity, as was the case with allozymes.

Based upon the groupings of populations using RAPDs and isozymes, we suggest that conservation and breeding programs for this species should include populations from at least the three clusters described in this study.

In order to examine the evolutionary causes of the observed genetic pattern, we applied a neutrality test and analyzed linkage disequilibrium according to Ohta's approach. We found evidence that migration and genetic drift are the most important evolutionary forces involved in the genetic structure of natural populations of "raulí". First, the neutrality test showed no evidence for selective forces on the RAPD loci, implying that these loci would have evolved only under genetic drift. Second, the D-statistics developed by Ohta (1982) to analyze causes of non-random associations of alleles did not show any evidence of systematic selection. Specifically, no allele combination was favored in particular geographic areas. This suggests that the observed nonsystematic linkage disequilibrium is likely due to limited gene flow and genetic drift, without a notable contribution of selection. Our results are a strong argument in favor of the hypothesis that stochastic demographic and random environmental factors have been the proximal causes of variation in RAPD loci in natural populations of "raulí".

\section{Acknowledgements}

We thank Mr. Oscar Chandía for assistance in the field. This work was funded by Fondecyt project $\mathrm{N}^{\circ} 1990933$. 
Resumen

\begin{abstract}
B. Carrasco, M. Garnier, L. Eaton, R. Guevara y M. Carú. 2009. Causas proximales de la variación genética entre y dentro de poblaciones de raulí (Nothofagus nervosa). Cien. Inv. Agr. 36(2):229-238. Se evaluó la diversidad genética de 587 individuos pertenecientes a 22 poblaciones naturales de raulí (Nothofagus nervosa), distribuidas a lo largo de la Cordillera de la Costa $\left(38^{\circ} \mathrm{S}\right.$ to $\left.41^{\circ} \mathrm{S}\right)$ y en la zona centro sur de Chile a través de la Cordillera de los Andes $\left(36^{\circ} \mathrm{S}\right.$ to $\left.40^{\circ} \mathrm{S}\right)$. El objetivo de este estudio fue complementar las inferencias genéticas previamente determinada por isoenzimas, para obtener estimaciones mas adecuadas de la diversidad genética. A partir de las 33 bandas RAPD analizadas se observó un promedio de $88,1 \%$ de loci polimórficos con valores que fluctuaron entre $33 \%$ y $63 \%$. El análisis análisis de varianza molecular (AMOVA) reveló que la mayor proporción de la variación genética se encuentra distribuída dentro de las poblaciones estudiadas (87,6\%). Sin embargo, el valor de $\mathrm{F}_{\mathrm{ST}}\left(\mathrm{F}_{\mathrm{ST}}=0.124 ; \mathrm{p}<0.00001\right)$ indicó que hay una significativa diferenciación entre poblaciones. El análisis discriminante mostró la existencia de tres grupos geográficos definidos con 14 loci explicando el $87,2 \%$ de la diferenciación genética entre poblaciones. La prueba de neutralidad de Watterson y el análisis de desequilibrio de ligamiento (LD) de Ohta sugieren que la variación detectada podría ser explicada en parte por factores estocásticos demográficos y ambientales. El rol de las últimas glaciaciones así como algunas medidas de conservación y mejoramiento es discutido.
\end{abstract}

Palabras clave: Estructura genética, Nothofagus, marcadores RAPD.

\section{References}

Allnutt, T.R., A. Newton, A. Lara, A. Premoli, J. Armesto, R., Vergara, and M. Gardner. 1999. Genetic variation in Fitzroya cupresoides (alerce) a threatened South American conifer. Mol. Ecol. 8:975-987.

Allnutt, T.R., A. Newton, A. Premoli, and A. Lara. 2003. Genetic variation in the threatened South American conifer Pilgerodendron uviferum $(\mathrm{Cu}-$ pressaceae) detected using RAPD markers. Biol. Conserv. 114:245-253.

Baruffi, L., G. Damiani, C.R. Guglielmino, C. Bandi, A.R. Malacrida, and G. Gasperi. 1995. Polymorphism within and between populations of Ceratitis capitata: comparison between RAPD and multilocus enzyme electrophoresis data. Heredity 74:425-437.

Begun, D., and C.F. Aquadro. 1993. African and North American populations of Drosophila melanogaster are very different at the DNA level. Nature 365:548-550.

Bekessy, S., T. Allnutt, A. Premoli, A. Lara, R. Ennos, M. Burgman, M. Cortes, and A. Newton.
2002. Genetic variation in the vulnerable and endemic Monkey Puzzle tree. detected using RAPDs. Heredity 88:243-249.

Bucci, G., and P. Menozzi. 1995. Genetic variation of RAPD markers in a Picea abies Karst. population. Heredity 75:188-197.

Bucci, G., G.G. Vendramin, L. Lelli, and F. Vicario. 1997. Assessing the genetic divergence of Pinus leucodermis Ant. endangered populations: use of molecular markers for conservation purposes. Theor. Appl. Genet. 95:1138-1146.

Carrasco, B. 1998. Patrones de Variabilidad Aloenzimática en Raulí (Nothofagus alpina Poepp et Endl (Oerst)). Efecto de su Sistema Reproductivo. Distribución Geográfica y Ultima Glaciación. Dissertation MSc. Facultad de Ciencias, Universidad de Chile. Santiago, Chile. pp. 94.

Carrasco, B., and L. Eaton. 2002. Natural history and genetic structure of raulí (Nothofagus nervosa (Phil.) Dim. Et Mil.). Forest Gen. 9:275-284.

Donoso, C. 1995. Bosques Templados de Chile y Argentina. Variación. Estructura y Dinámica. Editorial Universitaria. Santiago, Chile. 484 pp.

Doyle, J. 1991. DNA protocols for plants-CTAB total DNA isolation. Pages 283-293. In: G.M. Hewitt, 
and A. Johnston. (eds.). Molecular Techniques in Taxonomy. Springer-Verlag. Berlin. Germany.

Excoffier, L., P. Smouse, and J.M. Quattro. 1992. Analysis of molecular variance inferred from metric distances among DNA haplotypes: Application to human mitochondrial DNA restriction data. Genetics 131:479-491.

García, R., B. Carrasco, P. Penailillo, L. Letelier, R. Herrera, B. Lavandero, M. Moya, and P.D.S. Caligari. 2008. Genetic variability and structure of Gomortega keule (Molina) Baillon (Gomortegaceae) relict populations: geographical and genetic fragmentation and its implications for conservation. Botany 86:1-12.

Gustafson, D.J., D.J. Gibson, and D.L. Nickrent. 1999. Random amplified polymorphic DNA variation among remnant big bluestem (Andropogon gerardii Vitman) populations from Arkansas' Grand Prairie. Mol. Ecol. 8. 1693-1701.

Hadrys, H., M. Balik, and B. Schierwater. 1992. Applications of random amplified polymorphic DNA (RAPD) in molecular ecology. Mol. Ecol. 1:55-63.

Karl, S., and J. Avise. 1992. Balancing selection at allozyme loci in oysters: implications from nuclear RFLPs. Science 256:100-102.

Le Corre, V., S. Dumolin-Lapegue, and A. Kremer. 1997. Genetic variation at allozyme and RAPD loci in sessile oak Quercus petraea (Matt.) Liebl.: the role of history and geography. Mol. Ecol. 6:519-529.

Liedloff, A. 1999. Mantel Nonparametric Test Calculator for Windows Version 2.00. http://www. sci.qut.edu.au/nrs/mantel.htm. (Accessed: September 2008).

Mantel, N. 1967. The detection of disease clustering and a generalized regression approach. Cancer Res. 27:209-220.

Mattioni, C., M. Casasoli, M. González, R. Ipinza, and C. Villani. 2002. Comparison of ISSR and RAPD markers to characterize three Chilean Nothofagus species. Theor. Appl. Genet. 104:1064-1070.

Nei, M. 1973. Analysis of gene diversity in subdivided populations. Proc. Natl. Acad. Sci. USA. 70:3321-3323.

Nei, M. 1978. Estimation of average heterozygosity and genetic distance from a small number of individuals. Genetics 89:583-590.

Nybom, H. 2004. Comparison of different nuclear
DNA markers for estimating intraspecific genetic diversity in plant. Mol. Ecol. 13:1143-1155.

Ohta, T. 1982. Linkage disequilibrium due to ramdom drift in finite subdivided population. Proc. Natl. Acad. Sci. USA 79:1940-1944.

Peakall, R., P.E. Smouse, and D.R. Huff. 1995. Evolutionary implications of allozyme and RAPD variation in diploid populations of dioecious buffalograss [Buchloe dactyloides (Nutt.) Engelm.]. Mol. Ecol. 4:135-147.

Raymond, M., and F. Rousset. 1995. GENEPOP (version 1.2): population genetics software for exact tests and ecumenecism. J. Hered. 86:248249.

Souza, M.S., J.S. Puntieri, D. Barthélémy, and C. Brion. 2000. Bud Content and its Relation to Shoot Size and Structure in Nothofagus pumilio (Poepp. et Endl.) Krasser (Nothofagaceae) Ann. Bot. 85:547-555.

Van Den Ven, W., and R. McNicol. 1995. The use of RAPD markers for the identification of Sitka spruce (Picea sitchensis) clones. Heredity 75:126-132.

Veblen, T., C. Donoso, T. Kitzberger and A. Rebertus. 1996. Ecology of Southern Chilean and Argentinean Nothofagus forests. Pages 293-353. In: T.T. Veblen, R.S. Hill, and J. Read. (eds.). The Ecology and Biogeography of Nothofagus Forests. Yale University Press. Yale. Usa.

Villagrán, C. 1991. Historia de los bosques templados del sur de Chile durante el tardiglacial y el postglacial. Rev. Chil. Hist. Nat. 64:447-460.

Villagrán, C. 2001. A model for the history of vegetation of the Costal Range of central-southern Chile: Darwin's glacial hypothesis. Rev. Chil. Hist. Nat. 74:793-803.

Welsh, J., and M. McClelland. 1990. Fingerprinting genomes using PCR with arbitrary primers. Nucleic Acids Res. 18:7213-7218.

Williams, G., A. Kubelik, K. Livak, J. Rafalski, and S. Tingey. 1990. DNA polymorphisms amplified by arbitrary primers are useful as genetic markers. Nucleic Acids Res. 18:6531-6535.

Yeh, F., D. Chong, and R. Yang. 1995. RAPD variation within and among natural populations of trembling aspen (Populus tremuloides Michx.) from Alberta. J. Hered. 86:454-460.

Yeh, F.C., R. Yang, and T. Boyle. 1999. POPGENE 1.31. Quick user guide. University of Alberta and Centre for Internacional Forestry Research. 